\title{
Compensation strategies to enact new governance frameworks for SDG transformations
}

\author{
DAVID HORAN, PhD*
}

\author{
Article** \\ JEL: D61; D63; H11; H23; P26 \\ https://doi.org/10.3326/pse.43.4.3
}

\footnotetext{
* The author would like to thank David O'Connor for helpful feedback on an earlier draft; the two anonymous reviewers for their suggestions on how to improve the article and the guest editor of the Special Issue Louis Meuleman - for his kind invitation to write this paper and for the advice provided in the course of writing. The views expressed in this article are entirely the author's and are not necessarily held by the parties acknowledged herein. This project received funding from the European Commission and Irish Research Council Horizon 2020 research and innovation program under the Marie Sklodowska-Curie grant agreement 713279.
}

${ }^{* *}$ Received: August 23, 2019

Accepted: October 8, 2019

\section{David HORAN}

School of Politics and International Relations and the UCD Geary Institute for Public Policy, University College Dublin, Dublin, Ireland; Visiting Scholar, Sustainable Development Solutions Network (SDSN Association), New York, USA.

e-mail: david.horan@unsdsn.org,david.horan@ucd.ie,dgh2131@columbia.edu ORCiD: 0000-0001-9456-893X 


\section{Abstract}

There is an emerging consensus at international level that systemic transformations are needed to achieve the Sustainable Development Goals (SDGs). Such transformations require paradigm shifts in policies, with appropriate governance frameworks to implement them. Fundamental transformations are likely to generate winners and losers; the latter may act strategically to deter transformation. Most governance literature points at mutual gains negotiation methods to prevent the emergence of losers and create 'win-win' package deals. In this article a different - and less researched-approach will be discussed: (economic) compensation strategies. Drawing on the political economy literature of reform in transition economies, I propose three compensation strategies to buy out or weaken the opposition of strategic losers - big bang, optimal sequencing and divide-and-rule governance reforms - that can help to frame discussions around the political feasibility of new governance frameworks for SDG transformations. The paper suggests that careful consideration needs to be given to the design of these compensation packages, since history tells us that buying acceptance for reform can involve not just variation in economic outcomes, it can also have long-term political implications and distributional effects.

Keywords: sustainable development, governance reforms, political constraints, compensating transfers, energy decarbonisation, transition economies

\section{INTRODUCTION}

There is an emerging consensus among academics, researchers and policy makers concerned with how to achieve the Sustainable Development Goals (SDGs) that sustainable development requires systemic transformations (e.g., TWI2050, 2018; UNDESA, 2019; Sachs et al., 2019a). The World in 2050 (TWI2050) research initiative - a collaboration between the Sustainable Development Solutions Network (SDSN), the International Institute for Applied Systems Analysis (IIASA), the Stockholm Resilience Centre and Columbia University - proposes six exemplary transformations for achieving the SDGs and long-term sustainability: digital revolution; smart cities; energy decarbonization; sustainable consumption and production; sustainable food, biosphere and water, and human capacity and demography (TWI2050, 2018). There is less consensus in this literature, however, about how to implement these transformations, though it is widely held that crucially this requires fundamental shifts in public policy and governance, encompassing, for example, major reforms in areas such as economic and social policies, long-term integrated planning, public institutions and political processes, new stakeholder engagement mechanisms, aligned budgeting practices and procedures, among many others (SDSN and OECD, 2019; TWI2050, 2018; Schmidt-Traub, Obersteiner and Mosnier, 2019; OECD, 2019; UNDESA, 2019; Niestroy et al., 2019; Meadowcroft, 2011). These transformations need to be designed for, directed and adapted to country contexts, e.g., levels of development, political and social realities, local strengths, unique needs and governance structures (Sachs et al., 2019a). Each country must follow its own path and reforms that consider meta-governance, i.e., a pluralistic approach to governance of different 
governance styles, may be important as they are a way of dealing with context (UNCEPA, 2019; Meuleman, 2018; Meuleman and Niestroy, 2015; Niestroy, 2005).

Most important perhaps, relatively little is known about the political feasibility of different transformations in different contexts. It is recognized that transformations may be deeply political (Meadowcroft, 2011; Scoones, Leach and Newell, 2015; Smith and Stirling, 2010; Newell and Mulvaney, 2013; Cherp et al., 2018), and that this poses a challenge for governance, such as dealing with vested interests, the short-termism of policy and political cycles, the resistance of the wealthy to taxation, displaced workers and communities, deficits in representation, and the lack of public awareness of and support for transformation (e.g., TWI2050, 2018; Burch et al., 2019; Sovacool et al., 2017; Hausknost and Haas, 2019). What has not yet been researched in-depth is the impact on the feasibility of sustainability transformations of those who consider themselves 'losers' of the change.

This is a key question, as these transformations are likely to create winners and losers and the greatest obstacle to reform is often the opposition of vested interest groups that stand to lose most from changes in the status quo. For example, the U.S. Fossil Fuel Lobby has, through a combination of lobbying, regulatory capture, and investments in disinformation, consistently blocked the enactment of climate policies that might have facilitated energy decarbonization, despite mounting evidence of human-induced climate change and its effects (Hess, 2014; Geels, 2014; Brulle, 2014; Erickson et al., 2015; Erickson and Lazarus, 2013; Seto et al., 2016). This example and others like the agricultural lobbyists' role in blocking trade policy reforms (e.g. Baldwin, 2016) raise important questions about whether the governance reforms required for SDG transformations will generate 'strategic' losers, i.e. losers who try to block transformations, and if so, what, if anything, can, and should, be done to overcome this political constraint.

There are various ways to deal with opposition of 'losers'. Governance literature tends to promote mutual gains negotiation methods to prevent the emergence of losers and create 'win-win' package deals (Susskind and Field, 1996; Moomaw and Papa, 2012). This is a typical tool of the network governance approach, which is consensus-oriented, values trust, favours dialogue and partnerships, as well as other informal arrangements. In this article a different - and less researched approach will be discussed: (economic) compensation strategies for enacting reforms (e.g. Roland, 2002). This relates to the market governance style, which prefers market-based instruments like taxes and focuses on principles such as efficiency, competition, devolvement and empowerment (Meuleman, 2018). Indeed, these approaches could also be combined in some situations, e.g. when winners and 'losers' agree to engage in collaborative problem solving, to broaden the acceptance of SDG measures (Horan, 2019; Meuleman, 2018).

In public economics, the traditional approach to solving problems involving winners and losers requires the design of a tax and transfer system to offset the 
welfare losses of the losers by redistributing the gains of the winners (Kaldor, 1939; Hicks 1939; 1940). Subsequent research shows that the optimality of this approach depends on several considerations, such as how the transfer is financed (e.g. lump-sum or distortionary taxes), the ability to identify winners and losers to target transfers (e.g. asymmetric information), the size of the transfer (e.g. shortterm budget and borrowing constraints), as well as the economies' initial conditions and assumptions governing the partial and general equilibrium effects of the intervention (e.g. Kaplow, 2004; 2012; Hendren, 2014; Tsyvinski and Werquin, 2018). Increasingly, compensating transfers that account for these considerations are seen as a way to mitigate the negative effects of economic disruptions in areas such as immigration (Card, 2009), trade liberalization (Antras, de Gortari and Itskhoki, 2016), and technical change, e.g. automation, robotics, etc. (Katz and Murphy, 1992; Tsyvinski and Werquin, 2018).

Similar questions around the importance of political constraints in transition processes arise in older debates about pro-market reform in transition economies which focused on finding politically feasible reform paths. Here, opposing sides of the debate argued over the pace and sequencing of reforms, e.g. 'big bang' versus gradualist reform strategies, and, in particular, what reforms would buy out or weaken losers. Many reforms involved some amount of compensation to buy the acceptance of losers, typically managers and workers of state-owned companies and sectoral ministries (e.g., Shleifer and Treisman, 2000; Hoff and Stiglitz, 2005). These ranged from mass privatizations in Russia involving the giveaway of state assets to insiders, to partial privatizations in Poland and Hungary, to dual-track liberalization in China that liberalized prices at the margin while protecting the rents that various economic actors had under the planning system (Roland, 2002).

This article concentrates on compensation strategies to overcome political constraints to new governance frameworks for SDG transformations. It examines different strategies identified by the literature on the political economy of reform in transition economies and assesses their relevance to governance reforms for SDG implementation. It focuses primarily on compensation packages that governments could use to ease opposition from vested interests, such as the owners of fossil fuels, the beneficiaries of unsustainable land and ocean practices (e.g. TWI2050, 2018). Following Roland (2002), the article addresses two types of political constraints to governance reform, relevant in democratic contexts characterized by some degree of state capture by vested interests. First, there is political acceptability, such as, e.g., the willingness of the majority to accept reforms that involve compensating transfers to 'losers'. Second, there is, what I term, insider acceptability, such as the willingness of strategic losers, e.g. the fossil-fuel industry, to accept reforms given the compensation package offered to them.

Specifically, the paper identifies two key areas: strategic losers from governance reforms and the role of compensation strategies in the political economy of new governance frameworks that require greater attention and scrutiny in order to 
enact SDG transformations. I argue that the idea of compensating 'losers', e.g. the owners of fossil fuels, should be addressed more systematically in analyses of governance reforms when political will is essential for the success of the SDG transformation. The rationale for this is purely pragmatic: without such compensatory transfers, there is a risk that strategic losers will use their economic and political power to hinder support for these reforms and thus block transformations required to achieve the SDGs (Horan, 2019). This contrasts with the rationales given in the socio-technical literature on transitions which focus on justice and equity (e.g. Sovacool, 2014; Sovacool and Dworkin, 2015; Jenkins et al., 2016; Jenkins, McCauley and Forman, 2017; Sovacool et al., 2017).

Drawing on the political economy literature of reform in transition economies, this article proposes three compensation strategies to buy out or weaken the opposition of losers to new governance frameworks for SDG transformations - big bang, optimal sequencing and divide-and-rule governance reform strategies - that can help to frame discussions around the political feasibility of new governance frameworks. The article suggests that careful consideration needs to be given to the design of these compensation packages. Lessons from the transition economy experience tell us that buying acceptance for reform can involve not just variation in economic outcomes, it can also have long-term political implications and distributional effects (e.g. Roland, 2002). On the other hand, recent bank bailouts suggest such compensation packages need to go beyond piecemeal policy measures and enact comprehensive new governance frameworks to achieve transformation (e.g. Ferguson, Jorgenson and Chen, 2017; Thakor, 2018; Kane, 2018; Swagel, 2015; De Francesco and Maggetti, 2018; Grossman and Woll, 2014; TWI2050, 2018; UN, 2019).

This is not the first article on aspects of the political economy of governance reform for the SDGs. TWI2050 (2018) identifies five obstacles to SDG transformations, including vested interests and regulatory capture. Church, Crawford and Schaller (2019) propose foreign policy as a tool for overcoming obstacles. Horan (2019) and Nerini et al. (2019) assign a key role to multi-stakeholder partnerships. Socio-technical studies of energy transition highlight displaced workers, communities and vulnerable groups and the role of training in building their support for transition (Sovacool, 2014; Sovacool and Dworkin, 2015; Jenkins et al., 2016; Jenkins, McCauley and Forman, 2017; Sovacool et al., 2017), yet largely neglect negative impacts on owners and managers of fossil fuels, which can pose a bigger politico-economic obstacle to transition.

The article aims to contribute to the emerging literature on the governance frameworks required for SDG transformations (e.g. TWI2050, 2018; OECD, 2019; SDSN and OECD, 2019). This literature recognizes vested interests as an important obstacle to SDG transformations, e.g. owners of fossil fuel companies, those benefitting from unsustainable land and ocean practices such as cattle ranchers and fishing fleets, and it adds to this literature by proposing compensatory strategies 
that could be used to overcome their opposition to new governance reforms to initiate these transformations, highlighting there are different ways to deal with strategic losers, the political feasibility of which likely varies across countries.

The article also aims to add to the literature on sustainability governance (e.g. Meuleman, 2018; Meuleman and Niestroy, 2015; Meadowcroft, Farell and Spangenberg, 2005). This literature argues that sustainable development is above all about getting the governance right (e.g. Meadowcroft, 2011: 536), and four main governance approaches are identified - hierarchical, network, market and metagovernance (e.g. Meuleman, 2008; 2018, Larasson, 2015; Jessop, 2011; Sorensen, 2006; Kooiman, 2003; Powell et al., 1991; Thompson et al., 1991; Thorelli, 1986). This article addresses vested interests as an obstacle to sustainability transformations, focusing on strategic losers and removing their hold on governance and policy (e.g. Treadway et al. 2005; Painter, 2014). It supplements the mutual gains negotiation approach (Susskind and Field, 1996; Susskind, McKearnen and Thomas-Larmer, 1999; Moomaw and Papa, 2012; Barrett, 2002), with an economic approach based on compensation strategies, highlighting some strengths and weaknesses with the approach.

\section{GOVERNANCE REFORMS FOR SDG TRANSFORMATIONS}

This section briefly describes the main elements of new governance frameworks advocated in the growing literature on SDG transformations. This literature recognizes the enormous and complex governance challenges posed by sustainable development, and consequently, the frameworks proposed in this policy-oriented literature set out economic, social and political reforms. Together, these reforms, if implemented in full, would represent a major paradigm shift from existing national-level governance frameworks for the SDGs. It is difficult to ascertain exante the extent to which such frameworks can succeed in achieving transformation, but they are likely to be met with considerable opposition from strategic losers and require broad public support for their implementation.

SDG transformations are a way to organize the implementation of the SDGs (SDSN and OECD, 2019). The approach draws heavily on analyses that map out interdependencies among SDG outcomes (e.g. Nilsson, Griggs and Visbeck, 2016; ICSU and ISSC, 2016). Each transformation, e.g. energy decarbonization, groups key SDG interventions, i.e. interventions that generate significant economic, social and environmental co-benefits, such as access to clean energy, zero-carbon electricity generation, energy efficiency, electrification and zero-carbon fuels, and curbing pollution, in a single area, e.g. the energy system, with the aim of synergistically achieving multiple SDGs (Sachs et al., 2019b). For example, energy decarbonization is expected to contribute directly to SDGs 3, 6, 7, 9, 11-15 and to reinforce several other goals (Sachs et al., 2019b). In a similar way, SDG transformations are proposed for other areas such as education, health systems, urban infrastructure, ecosystems and agriculture, as well as digital technologies (e.g. SDSN, 2019; UNDESA, 2019; SDSN and OECD, 2019; TWI2050, 2018). Together, the transformations offer, at the 
very least, an entry point for governments to achieve the SDGs (TWI2050, 2018; UNDESA, 2019). To operationalize transformations, long-term policy pathways or plans are proposed that organize interventions around time-bound measurable targets, interim milestones, problems to be solved and potential solutions, pathways that need to be adapted to local contexts (SDSN, 2019; SDSN and OECD, 2019).

To guide the development of governance frameworks for SDG transformations, there is a large literature on transitions and transition management that spans several disciplines and domains. Most of this literature has looked into specific issues or sectors, such as economic systems and market forces (Nee, 1989; Roland, 2002; Weitzman, 1993), politics, power and democracy (Adler and Webster, 1995; De Soysa, Oneal and Park, 1997; Lemke and Reed, 1996; Linz and Stepan, 1996; Offe and Adler, 1991), energy (Kern and Smith, 2008; Meadowcroft, 2009; Meadows et al., 1972; Batinge, Musango and Brent, 2019), health (Frenk et al., 1991; Mackenbach, 1994), environment (van den Bergh, 2007). Whereas economic studies on transition tend to focus on economic instruments and consequences (e.g. privatization and its efficiency effects, climate policies and their economic costs), later studies, especially those from sociology, highlight societal change, social policies and the need to build public support for transition (e.g. displaced workers and retraining) (e.g. Sovacool, 2014; Sovacool and Dworkin, 2015; Jenkins et al., 2016; Jenkins, McCauley and Forman, 2017; Sovacool et al., 2017). More recent studies identify politics, power dynamics and political economy as a third essential ingredient in transition management (e.g. Healy and Barry, 2017; Cherp et al., 2018; Geels, 2014; Newell and Mulvaney, 2013).

In the literature on SDG transformations, The World in 2050 Report goes furthest in capturing the scale of the governance challenges facing sustainable development (TWI2050, 2018). It draws on many salient developments in theory and practice from different disciplinary perspectives on transition management. To support transformations, the report proposes, roughly, an equal number of policy reforms in each dimension of sustainable development, covering (1) economic reforms in fiscal frameworks, corrective pricing, direct regulation, development financing, publicly directed R\&D, among others; (2) political reforms for integrated planning, public deliberation, partnerships, independent planning agencies, cross-border cooperation, democratic oversight of science and technology, official SDG data; and (3) social reforms for public awareness, social norms and cultural innovations, grassroots activism, investment activism, consumer activism, shareholder activism and moral activism (TWI2050, 2018:, 24-27). Overall, it sets out a requirement for a wide range of policy instruments to steer the economy and society towards transformations, and avoids the tendency to overemphasize economic instruments (e.g. tax-and-spend policies) and magic bullets (e.g. carbon pricing), and places an important emphasis on enabling political and social innovations.

The proposals of this research have yet to make significant inroads into national SDG policy frameworks. The Voluntary National Reviews (VNRs) make little 
reference to SDG transformations. However, according to the most recent SDSN report (2019), "many governments have asked the SDSN and members of its Leadership Council how they might organize the implementation of the SDGs" and the transformation approach could become more popular in the second cycle of VNRs, particularly in view of support for this approach from international agencies such as the UN, OECD and IIASA. For most countries, this would represent major governance restructuring. The governance reforms outlined for the SDGs in the first cycle of VNRs, 2015-19, largely focus on updating national sustainable development strategies to reflect the SDGs; determining the level of political engagement, mainstreaming and mapping of SDGs responsibilities across government ministries, the introduction of mechanisms for interdepartmental coordination, etc. (e.g. Niestroy et al., 2019; Kindornay, 2019; OECD, 2019; Sachs et al., 2019b). While countries differ in the scale and pace of reform (Sachs et al., 2019b, 2018), there is, for most countries, an enormous governance gap between the reforms that have been implemented and those that have been proposed for implementing suitable frameworks for SDG transformations, e.g. such as in the TWI2050 report.

To fill the governance gap, the SDG transformation literature recognizes five obstacles or points of resistance to governance reform. These are vested interests, such as the owners of fossil fuels and beneficiaries or unsustainable land and ocean practices, regulatory capture, the resistance of powerful elites to taxation, redistribution and regulation, the lack of planning due to short-run political cycles and weak government capacities, and a lack of public awareness and understanding about transformations (TWI2050, 2018). This article focuses on strategies for buying out or easing opposition from vested interests that may try to block the enactment of transformations.

\section{COMPENSATION STRATEGIES FOR ENACTING REFORM}

An interesting analogy can be drawn between the structural problems facing postSoviet economies on the eve of their transition from socialism to capitalism and the climate predicament facing today's fossil-fuel based capitalist economies.

In central and eastern Europe, several decades of unfettered state-run communism distorted the sectoral composition of output in these economies, with, for example, over-production of heavy manufactures and under-production of light manufactures and other consumer goods. After decades of built-up inefficiencies, a rapid restructuring was required to downsize the state sector and prepare the ground for the development of non-state sector enterprises. Whereas the managers and workers of state-owned companies and sectoral ministries posed a significant "vested interest" obstacle to capitalist reform in post-Soviet economies, it is the owners of fossil fuels that, arguably, present the greatest "vested interest" obstacle to energy decarbonization. In a similar way, in today's capitalist economies, several decades of not internalizing the environmental costs of economic activity, nor the externalities affecting clean energy technology development have over-pro- 
duced carbon-intensive goods and under-produced clean energy-intensive goods. The result is an over-sized fossil-fuel sector and a relatively small low-carbon energy sector. With planetary boundaries fast approaching (e.g. IPBES, 2019; WEF, 2019; IPCC, 2018; Grooten and Almond, 2018; Rockstrom et al. 2009), there is now an urgent and compelling case for a major restructuring of today's economies to correct these accumulated distortions.

Following the collapse of communism, it was widely believed that a window of opportunity existed in post-Soviet bloc countries for the enactment of pro-market reforms. This involved a shift from planned contracts in production; the removal or phasing out of price controls; the privatization of state-owned assets; the creation of a labour market; and the development of small and medium-sized private enterprises. Scholars debated whether these reforms should be adopted as fast as possible, and made as irreversible as possible (e.g. Lipton and Sachs, 1990; Balcerowicz, 1995), or through a more gradual sequencing of reforms that aimed to build support for further reforms (e.g. Dewatripont and Roland, 1992a, 1992b, 1995; Wei, 1997; McMillan and Naughton, 1992; Litwack and Qian, 1999). The most controversial of these debates focused on the privatization of state assets.

The concern for political constraints in the transition from socialism to capitalism led to significant developments in political economy theory concerned with the enactment of reform (e.g., Dewatripont and Roland, 1995; Roland, 2000). Two types of political constraints can be identified in transition processes: feasibility constraints affecting the enactment of reforms, termed ex-ante political constraints, and constraints to maintain reforms, once they are put in place, referred to as ex-post political constraints (Roland, 2002). This paper focuses on strategies to ease ex-ante political constraints, i.e. those on the enactment of reform, which is the first step towards initiating transformation.

\section{THREE COMPENSATION STRATEGIES TO ENACTING REFORM}

This article considers strategies to implement full reform, whether now or in the future. I focus on the big-bang and gradualist strategies proposed in the political economy literature. Drawing heavily on the review article of Roland (2002), the article considers three main strategies for relaxing political constraints so that full reforms can be enacted. These are,

(1) Compensating transfers to buy acceptance for full reform.

(2) Optimal sequencing of partial reforms aimed at building constituencies for further reform.

(3) Partial reform involving divide and rule tactics to reduce opposition to future reform.

The first strategy, compensating transfers to buy the acceptance of those who stand to lose from full reform, has deep roots in economic theory. The traditional solution to compensating potential losers standing in the way of reform that would otherwise generate net welfare gains requires the design of a tax and transfer 
system to offset the welfare losses of the losers by redistributing the gains of the winners (Kaldor, 1939; Hicks 1939; 1940). These transfers may require government to commit to a series of transfer payments to losers over time or an upfront payment of the net present value of these transfers (Roland, 2002).

It is well known that the solution is (Pareto) efficient if lump-sum transfers are an available policy instrument, the identities of the winners and losers are known exante, and there are no commitment constraints faced by government (Mirrlees, 1971). However, inefficiencies can arise if transfers are financed by distortionary taxes, or transfers involve leakages stemming from asymmetric information, i.e. if government cannot distinguish losers (Mirrlees, 1971; Lewis, Feenstra and Ware, 1989). Furthermore, the strategy may be infeasible given short-term budget and borrowing constraints or if government lacks a mechanism to credibly commit future government to a series of transfer payments over time (Roland, 2002).

It is important to distinguish financial and non-financial transfers. Financial transfers usually involve distortionary taxation. Roland (2002) points out that these distortions may have been especially high in transition economies, since at this time, government capacity for domestic resource mobilization was relatively low. However, compensation packages need not involve financial transfers (Martinelli and Tommasi, 1997). The mass privatization of state assets that favoured insiders in Russia and Czechoslovakia can be seen as a lump-sum transfer of real assets to buy political acceptance for pro-market reforms. Privatization usually has high policy reversal costs which can act as a credible device to buy out losers.

The second strategy, an optimal sequencing of reforms, starts with an initial partial reform, e.g. partial privatization. A key argument in favour of partial reform is gradualism, which argues that an appropriate sequencing of reforms can build constituencies for further reforms (e.g. Dewatripont and Roland, 1992b; 1995; Wei, 1997; McMillan and Naughton, 1992; Litwack and Qian, 1999). The main idea behind the optimal sequencing strategy is to target areas where reforms are expected to be more popular (Dewatripont and Roland, 1995). For example, in Hungary and East Germany, the most profitable firms tended to be privatized first (Gatsios, 1992; Carlin and Meyer, 1992), which can be seen as a way to build support for further privatization, leaving the least popular, and probably most expensive, e.g. large loss-making enterprises, until later (Roland, 2002).

The optimal sequencing strategy can be more attractive than compensating losers for full reform, if there is considerable heterogeneity in the distribution of losses from reform and uncertainty about the gains from reform (Dewatripont and Roland, 1992b). A positive resolution of uncertainty in areas with better prospects for "good" outcomes can then build wider support for reform in other areas (Roland, 2002). The strategy can be particularly attractive, because it lowers the cost of compensating losers, at least in the short-run, especially if there are high cost strategic losers from some reforms and high efficiency costs to raising funds 
(Dewatripont and Roland, 1992b; Nielsen, 1993). On the other hand, the strategy introduces distortions in terms of forgone efficiency gains from complete reform, especially if there are complementarities among reforms (Roland, 2002).

The third strategy, divide-and-rule tactics, is a gradualist strategy that aims to sequence reforms in such a way as to successively weaken the opposition from strategic losers to reform (e.g. Dewatripont and Roland, 1992a; Wei, 1997). This involves designing a sequence of compensation packages that successively undermine the status quo. The strategy aims to split strategic losers into small groups, and to offer compensation packages for reforms that make each group worse off in each successive round.

\section{SOME LESSONS FROM THE TRANSITION ECONOMY EXPERIENCE}

The post-Soviet economies have since undergone the changes commonly associated with capitalist development. Arguably, the most significant of these was the privatization of state assets, which involved significant asset stripping by insiders, in many countries. The various privatization schemes have shown enormous variation in terms of both their economic consequences and their political implications, effects largely unanticipated at the outset, which are difficult to capture in standard economic analyses (Roland, 2002). Most experts did not anticipate the political use of privatization as a compensation device, or its political implications, e.g. increased rent seeking and state capture, political instability, formation of large financial groups (Roland, 2002).

There is striking similarity between the economic effects of these various privatization schemes and the predictions from macroeconomic models of the impacts of climate policies on the economy (e.g. Stern, 2007; Nordhaus, 2008; IPCC, 2014 : 223-252). In most of the transition economies of central and eastern Europe, industry output declined after price liberalization, which extended for long periods particularly in countries that initiated big bang privatizations, and that were eventually compensated by growth thereafter (Dollar and Ljunggren, 1997). Countries that employed gradualist reforms generally experienced less pronounced or shorter economic contractions.

\section{APPLICATION TO THE SDGS}

This section outlines three compensatory strategies for dealing with strategic losers in the context of governance reforms for SDG transformations. It explores the political feasibility of these strategies for different stylized country examples, focusing on two main aspects relevant in a democratic context: the degree of public support for transformation and the extent of state capture by 'losers'.

I define full reform as the implementation of a new governance framework along the lines proposed in the TWI2050 report. Partial reform can take a wide variety of forms. Three examples, useful for our purposes, are 1) partial reform involving full reform in a particular geographic area, e.g. an administrative sub-region such 
as city, county or state, called geographic reform, 2) partial reform involving full reform in a specific sector, e.g. electricity or buildings, termed sectoral reform, and 3) partial reform involving full reform in one dimension of sustainable development, e.g. political, social or economic, called dimensional reform.

To illustrate the framework, I use suggestive examples from energy decarbonization and draw on studies of technical roadmaps for decarbonizing energy systems, covering sectors such as power, transport, buildings, and industrial processes that need to be localized to specific countries (e.g. SDSN and FEEM, 2019; IEA, 2017; SDSN and IDDRI, 2015).

The three compensation strategies for easing political constraints to governance reform are:

(1) Big-bang governance reform.

(2) Optimal sequencing governance reform.

(3) Divide and rule governance reform.

Big-bang governance reform involves compensating or buying out strategic losers for the full implementation of a new governance framework. In the case of decarbonization, this would involve implementing the full set of proposed economic, social and political reforms in each of the four sectors in a particular country. Reforms may include corrective economic policy instruments, e.g. carbon tax, removal of fossil fuel subsidies, new fiscal frameworks for clean energy investments, green R\&D subsidies, regulatory standards such as emissions limits for buildings and vehicles, energy efficiency requirements, independent long-term planning agencies, institutions for public deliberation, new financial partnerships, public awareness campaigns, and support for social movements, etc. (TWI2050, 2018).

Optimal sequencing governance reform involves enacting partial governance reform in areas, sectors or dimensions of sustainable development that are likely to generate positive outcomes that can help to build support for further reforms in other areas, sectors or dimensions. For example, this might involve implementing full reform in electricity, which is expected to be the easiest-to-decarbonize sector, in the hope of creating support for future reform in transport, which is expected to be a more difficult-to-decarbonize sector, and so on (Lazard, 2017; Davis et al., 2018). Alternatively, it could involve full reform in cities or states where the prospects for good outcomes are high in the hope of building support for reform in other cities or states with weaker prospects. Similarly, it could involve a sequence of reforms that focuses first on political reforms, then social reforms and finally economic reforms (or vice versa). In practice, the optimal sequence of compensation packages may mix aspects of geographic, sectoral and dimensional governance reform.

Divide-and-rule governance reform involves implementing a sequence of partial reforms that aims successively to undermine the opposition of 'losers' to further reform. The strategy involves dividing 'losers' into smaller groups and building 
coalitions for reform in areas, sectors or dimensions that are significant sources of revenue or rent for the remaining losers. By successively implementing such reforms, the strategy seeks to iteratively weaken the opposition of 'losers' by lowering the required compensation packages to buy their acceptance for reform.

To assess the political feasibility of the each of the strategies in different contexts or countries, I focus on democratic countries and outline three types of stylized countries.

The first type of country is referred to as the progressives. These are countries characterized by strong public support for transformation and a government that is weakly captured by strategic losers, i.e. compensation packages could be designed to buy the acceptance of 'losers' for full reform. In the case of decarbonization, these might be countries where there is a majority of citizens who rank climate policy as a high priority policy issue, a small fossil-fuel sector and rapidly growing green economy. Leading examples of such countries might be Denmark, Finland, Iceland or Spain.

The second type of country is the captured. These are countries with governments that are strongly captured by potential 'losers' of transformations, such that feasible reform packages could only buy a small amount of governance reform. In the case of decarbonization, these countries typically have large fossil-fuel sectors. Among these countries, it is useful to distinguish first, those with weak public support for decarbonization, e.g. Russia, and those with majority support for public action to reduce GHG emissions, e.g. USA. Second, it is also useful to distinguish these countries by the importance for their fossil fuel sectors of domestic markets, e.g. USA, and those that depend primarily on foreign markets for revenue, e.g. Norway. ${ }^{1}$ The size of the green energy sector in captured countries can differ widely, e.g. compare Russia, USA and Norway.

The third type of country I refer to as the moderates. These countries may have average or even strong public support for SDG transformations. However, their governments are moderately captured by strategic losers, i.e. compensation packages can only succeed in buying partial reform. In the case of decarbonization, countries with a large fossil-fuel sector that have made some notable efforts in developing green energy are likely to qualify as moderates. A leading example of such a country is Germany.

\section{POLITICAL FEASIBILITY}

I now outline four hypotheses concerning the political feasibility of compensation strategies for dealing with strategic losers in the differently stylized countries. A short motivation in support of each hypothesis is given. Table 1 summarizes the main hypotheses presented in this section:

\footnotetext{
$\overline{{ }^{1} \text { See, e.g. IRENA (2019). }}$
} 
TABLE 1

Hypothesized compensation strategies for enacting new governance frameworks

\begin{tabular}{|c|c|c|c|c|c|}
\hline $\begin{array}{l}\text { Stylized } \\
\text { country }\end{array}$ & $\begin{array}{l}\text { State } \\
\text { capture }\end{array}$ & $\begin{array}{l}\text { Public } \\
\text { support }\end{array}$ & $\begin{array}{l}\text { Hypothesized } \\
\text { strategy }\end{array}$ & $\begin{array}{l}\text { Level of } \\
\text { implementation }\end{array}$ & $\begin{array}{l}\text { Possible } \\
\text { examples }\end{array}$ \\
\hline Progressive & Weak & $\begin{array}{l}\text { Majority } \\
\text { will }\end{array}$ & Big bang & $\begin{array}{l}\text { National, } \\
\text { subnational }\end{array}$ & $\begin{array}{l}\text { Spain, } \\
\text { New York }\end{array}$ \\
\hline Moderate & Moderate & $\begin{array}{l}\text { Majority } \\
\text { will }\end{array}$ & $\begin{array}{l}\text { Optimal } \\
\text { sequencing }\end{array}$ & $\begin{array}{l}\text { National, } \\
\text { subnational }\end{array}$ & $\begin{array}{l}\text { Germany } \\
\text { California }\end{array}$ \\
\hline Captured & Strong & Moderate & $\begin{array}{l}\text { Divide-and- } \\
\text { rule } \\
\text { (internal) }\end{array}$ & Subnational & $\begin{array}{l}\text { U.S.A. } \\
\text { (NY, } \\
\text { California) } \\
\end{array}$ \\
\hline Captured & Strong & Strong & $\begin{array}{l}\text { Divide-and- } \\
\text { rule } \\
\text { (external) }\end{array}$ & $\begin{array}{l}\text { Import } \\
\text { jurisdictions }\end{array}$ & $\begin{array}{l}\text { Norway } \\
\text { (EU) }\end{array}$ \\
\hline
\end{tabular}

Hypothesis 1: If there is weak state capture and a majority will for reform, then a big bang governance reform strategy is likely to be politically feasible in progressive countries.

This hypothesis is motivated by recent examples such as the Green New Deals of Spain and New York, California's Renewable Portfolio Standards, Iceland's Climate Action Plan 2018-2030, among others, as well as the pioneering roles some countries played in climate and energy policies, e.g. Denmark, Sweden, Finland (CPUC, 2017; Sovacool, 2017). ${ }^{2}$ These examples suggest: there are administrations willing to lead on decarbonization and fuller (political and social) reforms could be feasible with appropriately designed compensation packages to broaden acceptance for such reforms.

Hypothesis 2: If there is moderate state capture and a majority will for reform, then optimal sequencing of governance reforms is likely to be politically feasible in moderate countries.

The German experience with Energiewende, its Coal Exit Commission and government support for clean energy investments suggests there are countries where an optimal sequencing of governance reforms that aim to gradually phase out the fossil-fuel sector may be politically feasible, despite significant capture of the state by these interests. In such contexts, better designed compensation packages could be important for improving the effectiveness of existing reforms and broadening support for future reforms. ${ }^{3}$

\footnotetext{
${ }^{2}$ See New York's Climate Mobilization Act, April 2019. For Iceland's Climate Action Plan 2018-2030, see Ministry for the Environment and Natural Resources (2018). For a more recent announcement at the Climate Action Summit 2019 by New Zealand, Costa Rica, Fiji, Iceland and Norway to negotiate a new 'Agreement on Climate Change, Trade and Sustainability', see Steenblik and Droege (2019).

${ }^{3}$ For a critique of German Energiewende that focuses on competing interests, uncoordinated government ministries and weaknesses in the hierarchical, part captured, governance model used for transition, see Dohmen (2019). See also Coggio and Gustafson (2019).
} 
Hypothesis 3: If there is strong state capture and public support for reform, then a divide-and-rule governance reform strategy is likely to be politically feasible in captured countries with large domestic markets.

In captured countries, if there is significant heterogeneity across subnational administrative units in terms of local government capture and local majority will for reform, then subnational governments could be encouraged to adopt either full or partial reforms, particularly if these governments are progressive or moderate respectively. The idea here is to implement geographic reform in subnational areas or sectoral reform that will weaken the position of vested interests at the national level. If successful, these reforms could build constituencies for further reform in other areas or sectors and thus, successively lower the required compensation packages for buying reforms at national level.

It is recognized that subnational and non-state actors may have an important role in climate mitigation (e.g. Hsu et al., 2016; Hale, 2016; Chan et al., 2015; Hale and Roger, 2014). In the case of the United States at federal level, it is unlikely compensating transfers would have public or lobby support given the size and influence of its fossil-fuel industry. For example, in 2014, the profits of public companies engaged in fossil-fuel activities in North America were \$257 billion and $\$ 326$ million was invested in lobbying and campaign funds in the $113^{\text {th }}$ Congress. ${ }^{4}$ Yet, a divide-and-rule strategy may be feasible because states and sectors differ in terms of public support for climate actions and regulatory capture.

For example, California has recently implemented stricter vehicle emission standards than the Federal government, standards that have been adopted in thirteen other states. California accounts for $12 \%$ of all vehicle sales in the USA and together with the thirteen other states, they collectively account for approximately one third of the US car market. ${ }^{5}$ Similarly, the 2008-09 auto-industry bailout involved stricter Federal vehicle emission standards. These examples suggest that subnational and sectoral reforms can potentially weaken the market shares of dominant fossil fuel interests and therefore, the compensation required to buy acceptance for governance reform at federal level.

Hypothesis 4: If there is strong state capture in an exporting country, then a divideand-rule strategy is likely to be politically feasible if the import countries are progressive/moderate.

Whereas hypothesis three exploits fragmentation within captured countries, this hypothesis is based on fragmentation outside these countries. The main idea is that implementation of full or partial reform in markets that are key sources of revenue or rents for strategic losers of another country could ease opposition to reform in that country.

\footnotetext{
${ }^{4}$ See http://priceofoil.org/profits-oil-gas-coal-companies-operating-u-s-canada/.

${ }^{5}$ See https://www.bbc.com/news/world-us-canada-49746701.
} 
For example, Norway, like many oil producing nations, exports much of its oil and gas, and despite strong domestic support for climate action, its welfare system and support for its government depend, at least in part, on these export revenues (IRENA, 2019: 33). Progressive reforms in EU countries, the principal export destination, especially in transport, could help to weaken the opposition of the Norwegian Petroleum Industry to compensatory reforms. Such compensation packages will likely require the participation of regional partners, e.g. packages similar to EU Structural Funds.

\section{DISCUSSION}

The article outlines a set of strategies that can be used for implementing new governance frameworks for SDG transformations. At the core of each of these strategies is the idea of compensating strategic losers to buy their acceptance for governance reforms to prevent their continued blocking of transformations necessary for achieving the SDGs.

A limitation of the article is that it does not trace out the likely effects of each of these strategies, focusing instead on their political feasibility across stylized country examples. However, I believe that the identification of these strategies can provide a useful point of reference for framing discussions about how to implement new governance frameworks for sustainable development. Such a framing is lacking in current debates on governance for SDG transformations, which tend to focus on the characteristics of good governance frameworks, rather than how to deal with strategic losers, i.e. those who stand to lose most from changes in the status quo.

More research is needed on how to optimally design compensation packages to buy the acceptance of losers from governance reforms. The paper has not built a model to identify the characteristics of optimal compensation in the context of SDG transformations. The transition economy experience highlights that different compensation packages can lead to enormous variation in their effects. Important consideration needs to be given not just to economic effects, but also to the political and social implications of such reform packages. The case of Russia highlights that poorly designed compensation packages can serve to simply increase the power of vested interests with the benefits of reform concentrated within these interests. The bank and auto-industry bailouts suggest piecemeal policy changes are unlikely to achieve transformation (e.g. Dellisanti and Wagner, 2018; McNulty and Wisner, 2014). These bailouts highlight government's willingness to spend large amounts of money on strategic losers in a crisis and the importance of getting a good deal for the public in terms of new governance frameworks. Research is also needed on the appropriate mix of financial and non-financial compensation, e.g. stock options in the green economy, and how costs ought to be distributed across generations. There is a strong case for debt-financed compensation that transfers much of the cost to future generations (e.g., Sachs, 2015). 
The article proposes three compensation strategies for enacting governance reforms. However, other strategies are also possible. For example, the political economy literature refers to dual-track price liberalization, as was used in China, as a successful example of a gradualist strategy to implement capitalist reform (Roland, 2002). In a decarbonization context, a dual track strategy may be to maintain existing contracts for strategic losers, e.g. coal power plants, but to implement new governance reforms at the margin, e.g. require additional contracts use green energy. Compensation in this approach is implicit; the coal industry keeps its existing contracts (Burtraw and Palmer, 2008).

Such a strategy may be an important building block for governance reforms to emerge that later could be combined with the compensation strategies outlined in this article to buy the acceptance of losers for fuller reform. Germany appears to have a dual-track energy system and compensation packages may now be needed to improve the effectiveness of the phase-out of coal. A dual-track strategy may also be useful for progressive or moderate countries in the developing world as way of dealing with increasing demands for both energy and climate commitments.

More research is also needed to examine the political feasibility of transformations in different contexts. This paper has considered two highly stylized aspects of democratic systems, yet political feasibility is more contextual than suggested here and the relevance of other aspects needs to be assessed. For example, a limitation of the proposed strategies is the potential for retaliation. In response to California's stricter emission controls, the US Federal government stripped the state of its right to set its own vehicle emission standards, which is now likely to spark a legal battle over states' rights. Further research is also needed to understand political feasibility in developing countries and non-democratic settings, e.g. authoritarian regimes, fragile states.

\section{Disclosure statement}

No potential conflict of interest was reported by the author. 


\section{REFERENCES}

1. Adler, G. and Webster, E., 1995. Challenging Transition Theory: the Labor Movement, Radical Reform, and Transition to Democracy in South Africa. Political Sociology, 23(1), pp. 75-75. https://doi.org/10.1177/0032329295023001004

2. Antras, P., De Gortari, A. and O. Itskhoki, 2017. Globalization, Inequality and Welfare. Journal of International Economics, 108, pp. 387-412. https://doi. org/10.1016/j.jinteco.2017.07.009

3. Balcerowicz, L., 1995. Socialism, Capitalism, Transformation. Budapest: Central European University Press.

4. Baldwin, R. 2016. The World Trade Organization and the Future of Multilateralism. Journal of Economic Perspectives, 30(1), pp. 95-116. https://doi.org/ 10.1257/jep.30.1.95

5. Barrett, S., 2002. Environment and Statecraft: The Strategy of Environmental Treaty Making. Oxford Oxford University Press.

6. Batinge, B., Musango, J. K., and Brent, A. C., 2019. Sustainable Energy Transition Framework for Unmet Electricity Markets. Energy Policy, 129, pp. 1090-1099. https://doi.org/10.1016/j.enpol.2019.03.016

7. Brulle, R. J., 2014. Institutionalizing Delay: Foundation Funding and the Creation of U.S. Climate Change Counter-movement Organizations. Climate Change, 122(4), pp. 681-694. https://doi.org/10.1007/s10584-013-1018-7

8. Burch, S. [et al.], 2019. New Directions in Earth System Governance Research. Earth System Governance, 1, pp. 1-18. https://doi.org/10.1016/j.esg.2019. 100006

9. Burtraw, D. and Palmer, K. 2008. Compensation Rules for Climate Policy in the Electricity Sector. Journal of Policy Analysis and Management, 27(4), pp. 819-847. https://doi.org/10.1002/pam.20378

10. Card, D. 2009. Immigration and Inequality. American Economic Review, 99(2), pp. 1-21.

11. Carlin, W. and Mayer, C., 1992. Restructuring Enterprises in Eastern Europe. Economic Policy, 15, pp. 311-46. https://doi.org/10.2307/1344545

12. Chan S. [et al.], 2015. Reinvigorating International Climate Policy: A Comprehensive Framework for Effective Non-state Action. Global Policy, 6(4), pp. 466-473 https://doi.org/10.1111/1758-5899.12294

13. Cherp, A. [et al.], 2018. Integrating techno-economic, socio-technical and political perspectives on national energy transitions: A meta-theoretical framework. Energy Research \& Social Science, 37, pp. 175-190. https://doi.org/ 10.1016/j.erss.2017.09.015

14. Church, C., Crawford, A. and Schaller S., 2019. Managing the Trade-offs of Transformations through Foreign Policy. Chapter 4 in D. Ivleva, S. Schaller and J. Vivekananda, eds. Driving Transformational Change: Foreign Affairs and the 2030 Agenda. Berlin: Adelphi.

15. Coggio, T. and Gustafson, T., 2019. When the Exit? The Difficult Politics of German Goal. German Politics and Society, 37(1), pp. 47-65. https://doi.org/ $10.3167 /$ gps.2019.370103 
16. CPUC 2017. Renewable Portfolio Standards. California Public Utilities Commission, Annual Report. November 2017.

17. Davis, S. J. [et al.], 2018. Net Zero Emission Energy System. Science, 360, pp. 1419-1428.

18. De Francesco, F. and Maggetti, M., 2018. Assessing Disproportionality: Indexes of Policy Responses to the 2007-2008 Banking Crisis. Policy Sciences, 51(1), pp. 17-38. https://doi.org/10.1007/s11077-017-9309-X

19. De Soysa, I., Oneal, J. R. and Park, Y. H., 1997. Testing power-transition theory using alternative measures of national capabilities. Journal of Conflict Resolution, 41, pp. 509-528. https://doi.org/10.1177/0022002797041004002

20. Dellisanti, D., and Wagner, R. E. 2018. Bankruptcies, Bailouts and Some Political Economy of Corporate Reorganization. Journal of Institutional Economics, 14(5), pp. 833-851. https://doi.org/10.1017/s1744137418000085

21. Dewatripont, M. and Roland, G., 1992a. Economic Reform and Dynamic Political Constraints. Review of Economic Studies, 59(4), pp. 703-30. https:// doi.org/10.2307/2297994

22. Dewatripont, M. and Roland, G., 1992b. The Virtues of Gradualism and Legitimacy in the Transition to a Market Economy. Economic Journal, 102(411), pp. 291-300. https://doi.org/10.2307/2234514

23. Dewatripont, M. and Roland, G., 1995. The Design of Reform Packages under Uncertainty. American Economic Review, 85(5), 1207-1223.

24. Dohmen, F., 2019. German Failure on the Road to a Renewable Future. Spiegel online, May 13, 2019.

25. Dollar, D. and Ljunggren, B., 1997. Vietnam in:P. Desai, ed. Going Global. Cambridge, Mass.: MIT Press, pp. 439-471.

26. Erickson P. and Lazarus, M. 2013. Assessing the Greenhouse Gas Emissions Impact of New Fossil Fuel Infrastructure. Seattle: Stockholm Environment Institute.

27. Erickson P, Lazarus M. and Tempest, K. 2015. Carbon Lock-in from Fossil Fuel Supply Infrastructure. Seattle: Stockholm Environment Institute.

28. Ferguson, T., Jorgenson, P. and Chen, J., 2017. Fifty Shades of Green: High Finance, Political Money, and the US Congress. Roosevelt Institute Working Paper.

29. Frenk, J. [et al.], 1991. Elements for a Theory of the Health transition. Health Transition Review, pp. 21-38.

30. Gatsios, K., 1992. Privatization in Hungary: Past, Present and Future. CEPR Discussion Paper, No. 642.

31. Geels, F. W. [et al.], 2017. Sociotechnical transitions for deep decarbonization. Science, 357(6357). pp. 1242-1244. https://doi.org/10.1126/science.aao3760

32. Geels, F. W., 2014. Regime resistance against low-carbon transitions: introducing politics and power into the multi-level perspective. Theory, Culture and Society, 31(5), pp. 21-40. https://doi.org/10.1177/0263276414531627

33. Grooten, M. and Almond, R .E. A. (eds.), 2018. Living Planet Report-2018: Aiming Higher Gland: WWF. 
34. Grossman, E. and Woll, C., 2014. Saving the Banks: The Political Economy of Bailouts. Comparative Political Studies, 47(4), pp. 574-600. https://doi. org/10.1177/0010414013488540

35. Hale, T., 2016. All Hands on Deck: The Paris Agreement and Nonstate Climate Action. Global Environmental Politics, 16(3). https://doi.org/10.1162/ glep_a_00362

36. Hale, T., and Roger, C., 2014. Orchestration and transnational climate governance. Review of International Organizations, 9(1), pp. 59-82. https://doi. org/10.1007/s11558-013-9174-0

37. Hausknost, D. and Haas, W., 2019. The Politics of Selection: Towards a Transformative Model of Environmental Innovation. Sustainability, 11(2). https:// doi.org/10.3390/su11020506

38. Healy, N. and Barry, J., 2017. Politicizing Energy Justice and Energy System Transitions: Fossil Fuel Divestment and a "Just Transition". Energy Policy, 108, pp. 451-459. https://doi.org/10.1016/j.enpol.2017.06.014

39. Hendren, N. 2014. Efficient Welfare Weights. NBER Working Paper, No.20351.

40. Hess, D. J., 2014. Sustainability Transitions: A Political Coalition Perspective, Research Policy, 43(2), pp. 278-283. https://doi.org/10.1016/j.respol.2013.10.008

41. Hicks, J. R., 1939. The Foundations of Welfare Economics. The Economic Journal, 49(196), pp. 696-712.

42. Hicks, J. R., 1940. The Valuation of the Social Income. Economica, 7(26), pp. 105-124.

43. Hoff, K. and Stiglitz, J. E., 2005. The creation of the rule of law and the legitimacy of property rights: the political and economic consequences of a corrupt privatization (English). Policy, Research working paper, No. WPS 3779. https://doi.org/10.3386/w11772

44. Horan, D., 2019. A New Approach to Partnerships for SDG Transformations. Sustainability, 11(18), 4947, pp. 1-23. https://doi.org/10.3390/su11184947

45. Hsu, A. [et al.], Yick 2016. Track climate pledges of cities and companies. Nature 532, pp. 303-305. https://doi.org/10.1038/532303a

46. ICSU and ISSC 2016. A Draft Framework for Understanding SDG Interactions. International Council for Science; available at http://bit.ly/sdg- interactions

47. IEA, 2017. World Energy Outlook 2017. International Energy Agency.

48. IPBES, 2019. 2019 Global Assessment Report on Biodiversity and Ecosystem Services, A Summary for Policy Makers. https://doi.org/10.1111/padr.12283

49. IPCC, 2014. Climate Change 2014: Mitigation of Climate Change. Contribution of Working Group III to the Fifth Assessment Report of the Intergovernmental Panel on Climate Change. Cambridge: Cambridge University Press. https://doi.org/10.1017/cbo9781139151153.002

50. IPCC, 2018. Summary for Policymakers. In: Global warming of $1.5^{\circ} \mathrm{C}$. An IPCC Special Report on the impacts of global warming of $1.5^{\circ} \mathrm{C}$ above preindustrial levels and related global greenhouse gas emission pathways, in the 
context of strengthening the global response to the threat of climate change, sustainable development, and efforts to eradicate poverty. Geneva: World Meteorological Organization. https://doi.org/10.4135/9781483351384.n48.

51. IRENA, 2019. A New World: The Geopolitics of Energy Transformation. Report by the Global Commission on the Geopolitics of Energy Transformation. https://doi.org/10.1093/gmo/9781561592630.article.50657

52. Jenkins, K. [et al.], 2016. Energy justice: a conceptual review. Energy Research and SocialScience, 11,pp. 174-182.https://doi.org/10.1016/j.erss.2015.10.004

53. Jenkins, K., McCauley, D. and Forman, A., 2017. Energy justice: A policy approach. Energy Policy, 109, pp. + 825-834.

54. Jessop, B. 2011. Metagovernance. In: M. Bevir, ed. The Sage Handbook of Governance. London: Sage.

55. Kaldor, N., 1939. Welfare Propositions of Economics and Interpersonal Comparisons of Utility. The Economic Journal, 49(195), pp. 549-552. https://doi. org/10.2307/2224835

56. Kane, E. J., 2018. Why Dodd Frank is a Shell Game for Banks. Institute for New Economic Thinking.

57. Kaplow, B. L., 2012. Optimal Control of Externalities in the Presence of Income Taxation. International Economic Review, 53(2), pp. 487-509. https:// doi.org/10.1111/j.1468-2354.2012.00689.x

58. Kaplow, L., 2004. On the (Ir)relevance of Distribution and Labor Supply Distortion to Government Policy. Journal of Economic Perspectives, 18(4), pp. 159-175. https://doi.org/10.1257/0895330042632726

59. Katz, L. F. and Murphy, K. M., 1992. Changes in Relative Wages, 1963-1987: Supply and Demand Factors. The Quarterly Journal of Economics, 107(1), pp. 35-78. https://doi.org/10.2307/2118323

60. Kern, F. and Smith, A., 2008. Restructuring energy systems for sustainability? Energy transition policy in The Netherlands. Energy Policy, 36, pp. 40934103. https://doi.org/10.1016/j.enpol.2008.06.018

61. Kindornay, S., 2019. Progressing National SDG Implementation: An independent assessment of the voluntary national review reports submitted to the United Nations High-level Political Forum in 2018. Ottawa: Canadian Council for International Co-operation.

62. Kooiman, J., 2003. Governing as Governance. Sage, London, UK.

63. Larsson, O. 2015. The Governmentality of Meta-Goverance. Identifying Theoretical and Empirical Challenges of Network Governance in the Political Field of Security and Beyond. Uppsala: Acta Universitatis Upsaliensis. https:// doi.org/10.1086/ahr/78.4.1075

64. Lazard, 2019. Levelized Cost of Energy Analysis. Version 11.0. 2017.

65. Lemke, D. and Reed, W., 1996. Regime types and status quo evaluations: power transition theory and the democratic peace. International Interactions, 22, pp. 143-164. https://doi.org/10.1080/03050629608434886 
66. Lewis, T. R., Feenstra, R. and Ware, R., 1989. Eliminating Price Supports: A Political Economy Perspective. Journal of Public Economics, 40(2), pp. 159185. https://doi.org/10.1016/0047-2727(89)90001-7

67. Linz, J. J. and Stepan, A., 1996. Problems of Democratic Transition and Consolidation: Southern Europe. Revista Española de Investigaciones Sociológicas, (76), pp. 291-297 https://doi.org/10.2307/40184001

68. Lipton, D. and Sachs, J., 1990. Creating a Market Economy in Eastern Europe: the Case of Poland. Brookings Papers on Economic Activity, 1, pp. 75-133. https://doi.org/10.2307/2534526

69. Litwack, J. and Qian, Y., 1998. Balanced or Unbalanced Development: Special Economic Zones as Catalysts for Transition. Journal of Comparative Economics, 26(1), pp. 117-141. https://doi.org/10.1006/jcec.1997.1502

70. Mackenbach, J., 1994. The epidemiologic transition theory. Journal of Epidemiology Community Health, 48, pp. 329-331. https://doi.org/10.1136/jech. 48.4.329-a

71. Martinelli, C. and Tommasi, M., 1997. Sequencing of Reforms in the Presence of Political Constraints. Economics and Politics, 9(2), pp. 115-131.

72. McMillan, J. and Naughton, B., 1992. How to Reform a Planned Economy: Lessons from China. Oxford Review of Economic Policy, 8(1), pp. 130-143. https://doi.org/10.1093/oxrep/8.1.130

73. McNulty, P. A. and Wisner, J. D., 2014. The Impacts of the 2008 Government Bailouts of the U.S. Automobile Industry. The Journal of Human Resource and Adult Learning, 10(2), pp. 20-30.

74. Meadowcroft, J., 2009. What about the politics? Sustainable development, transition management, and long-term energy transitions. Political Science, 42, pp. 323-340. https://doi.org/10.1007/s11077-009-9097-z

75. Meadowcroft, J., 2011. Sustainable development. In: M. Bevir, ed. The Sage handbook of governance. London: Sage.

76. Meadowcroft, J., Farrell, K. and Spangenberg, J., 2005. Developing a Framework for Sustainability Governance in the European Union. International Journal of Sustainable Development, 8(1-2), pp. 3-11. https://doi.org/10.1504/ ijsd.2005.007371

77. Meadows, D. H. [et al.], 1972. The Limits to Growth: a Report to the Club of Rome. New York: Potomac Associates.

78. Meuleman, L. 2018. Meta-governance for Sustainability: A Framework for Implementing the Sustainable Development Goals. Routledge Studies in Sustainable Development. https://doi.org/10.4324/9781351250603

79. Meuleman, L. and Niestroy, I., 2015. Common but Differentiated Governance: A Meta-governance Approach to Make the SDGs Work. Sustainability, 7, pp. 12295-12321. https://doi.org/10.3390/su70912295

80. Meuleman, L., 2008. Public Management and the Metagovernance of Hierarchies, Networks and Markets: The Feasibility of Designing and Managing Governance Style Combinations. Heidelberg: Physica-Verlag Springer. https://doi.org/10.1057/ap.2009.12 
81. Ministry for the Environment and Natural Resources, 2018. Iceland's Climate Action Plan for 2018-2030 - Summary. Reykjavík: Ministry for the Environment and Natural Resources.

82. Mirrlees, J. A. 1971. An Exploration in the Theory of Optimum Income Taxation. The Review of Economic Studies, 38(2), pp. 175-208. https://doi. org/10.2307/2296779

83. Moomaw, W. and Papa, M., 2012. Creating a mutual gains climate regime through universal clean energy services. Climate Policy, 12, pp. 505-520. https://doi.org/10.1080/14693062.2011.644072

84. Nee, V., 1989. A theory of market transition: from redistribution to markets in state socialism. American Sociological Review, 54(5), pp. 663-681. https:// doi.org/10.2307/2117747

85. Nerini, F. F. [et al.], 2019. Connecting climate action with other Sustainable Development Goals. Nature Sustainability, 2, pp. 674-680. https://doi. org/10.1038/s41893-019-0334-y

86. Newell, P. and Mulvaney, D., 2013. The political economy of the "just transition". The Geographical Journal, 179, pp. 132-140. https://doi.org/10.1111/ geoj. 12008

87. Nielsen, C. K., 1993. Multi-stage versus single-stage reform: normative strategies for reducing status-quo bias in trade reform. Working Paper, Aarhus University.

88. Niestroy, I. , 2005. Sustaining Sustainability - A Benchmark Study on National Strategies towards Sustainable Development and the Impact of Councils in Nine EU Member States. Utrecht: Lemma.

89. Niestroy, I. [et al], 2019. Europe's approach to implementing the Sustainable Development Goals: good practices and the way forward. Study commission by European Parliament's Committee on Development, Policy Department, Directorate-General for External Policies.

90. Nilsson, M., Griggs, D. and Visbeck, M., 2016. Policy: Map the Interactions between Sustainable Development Goals. Nature, 534, pp. 320-22. https://doi. org/10.1038/534320a

91. Nordhaus, W. D., 2008. A Question of Balance: Weighing the Options on Global Warming Policies. New Haven: Yale University Press. https://doi. org/10.1162/glep.2009.9.1.146

92. OECD, 2019. Governance as SDG Accelerator: Country Experiences and Tools. Paris:OECD. https://doi.org/10.1787/0666b085-en

93. Offe, C., 1994. Capitalism by Democratic Design? Democratic Theory Facing the Triple Transition in Central and Eastern Europe. In: H. J. Wagener, ed. The Political Economy of Transformation. Studies in Contemporary Economics. Heidelberg: Physica, pp. 865-892. https://doi.org/10.1007/978-3-642-52404-2_2

94. Painter, M., 2014. Governance Reforms in China and Vietnam: Marketisation, Leapfrogging and Retrofitting. Journal of Contemporary Asia, 44, pp. 204220. https://doi.org/10.1080/00472336.2013.870829 
95. Powell, W. W. [et al,], 1991. Neither market nor hierarchy: Network forms of organisation. In: G. Thompson et al., eds. Markets, Hierarchies and Networks: The Co-Ordination of Social Life. London: Sage, pp. 265-276.

96. Rockström J., Steffen W., Noone K., Persson A., Chapin, F. S., et al. 2009. A Safe Operating Space for Humanity. Nature, 461(7263), pp. 472-475.

97. Roland, G. 2002. The Political Economy of Transition. Journal of Economic Perspectives, 16(1), pp. 29-50.

98. Roland, G., 2000. Transition and Economics: Politics, Firms, Markets. Cambridge, Mass.: MIT Press.

99. Sachs, J. et al., 2019a. Six Transformations to achieve the Sustainable Development Goals. Nature Sustainability, (2), pp. 805-814. https://doi.org/10.1038/ s41893-019-0352-9

100. Sachs, J. et al., 2019b. Sustainable Development Report 2019. New York: Bertelsmann Stiftung and Sustainable Development Solutions Network (SDSN).

101. Sachs, J., 2015. Climate Change and Intergenerational Well-being. In: L. Bernard and W. Semmler, eds. Oxford Handbook of the Macroeconomics of Global Warming. Oxford: Oxford University Press. https://doi.org/10.1093/ oxfordhb/9780199856978.013.0011

102. Schmidt-Traub, G., Obersteiner, M. and Mosnier, A., 2019. Fix the broken food system in three steps. Nature. International Journal of Science, 569, pp. 181-183. https://doi.org/10.1038/d41586-019-01420-2

103. Scoones, I., Leach, M. and Newell, P., 2015. The Politics of Green Transformations. London: Routledge.

104. SDSN and FEEM, 2019. Roadmap to 2050: A Manuel for Nations to Decarbonize by Mid-Century. Sustainable Development Solutions Network (SDSN) and Fondazione Eni Enrico Mattei (FEEM).

105. SDSN and IDDRI 2015. "Pathways to Deep Decarbonization 2015 Report." Deep Decarbonization Pathways (DDPP) Project.

106. SDSN and OECD, 2019. Long-term Pathways for the Implementation of the SDGs: The Governance Implications. A Reflection Paper.

107. Seto K. C. [et al.], 2016. Carbon Lock-in: Types, Causes and Policy Implications. Annual Review of Environment and Resources, 41, pp. 425-452. https:// doi.org/10.1146/annurev-environ-110615-085934

108. Shleifer, A. and Treisman, D., 2000. Without a Map: Political Tactics and Economic Re form in Russia. Cambridge: MIT Press. https://doi.org/10.2458/ v7i1.21571

109. Smith, A. and Stirling, A., 2010. The Politics of Socio-ecological Resilience and Sustainable Socio-technical Transitions. Ecological Sociology, 15, pp. 11. https://doi.org/10.5751/es-03218-150111

110. Sorensen, R., 2006. Metagovernance: The Changing Role of Politicians in Processes of Democratic Governance. The American Review of Public Administration, 36, pp. 98-114. https://doi.org/10.1177/0275074005282584 
111. Sovacool, B. K. [et al.], 2017. New frontiers and conceptual frameworks for energy justice. Energy Policy, 105, pp. 677-691. https://doi.org/10.1016/j. enpol.2017.03.005

112. Sovacool, B. K. and Dworkin, M. H., 2015. Energy justice: Conceptual Insights and Practical Applications. Applied Energy, 142, pp. 435-444. https://doi.org/10.1016/j.apenergy.2015.01.002

113. Sovacool, B. K., 2014. What are we doing here? Analyzing fifteen years of energy scholarship and proposing a social science research agenda. Energy Research and Social Science, 1, pp. 1-29. https://doi.org/10.1016/j.erss. 2014.02.003

114. Steenblik, R. P. and Droege, S., 2019. Time to ACCTS? Five countries announce new initiative on trade and climate change. International Institute for Sustainable Development.

115. Stern, N. H. 2007. The Economics of Climate Change: The Stern Review. Cambridge: Cambridge University Press.

116. Susskind, L. and Field, P., 1996. Dealing with an Angry Public: The Mutual Gains Approach to Resolving Disputes. New York: Free Press.

117. Susskind, 1., McKearnen, S. and Thomas-Larmer, J., 1999. The Consensus Building Handbook. Thousand Oaks: SAGE.

118. Swagel, P. 2015. Legal, Political, and Institutional Constraints on the Financial Crisis Policy Response. Journal of Economic Perspectives, 29 (2), pp. 107-122. https://doi.org/10.1257/jep.29.2.107

119. Thakor, A. V. 2018. Post-crisis Regulatory Reform in Banking: Address Insolvency Risk, NOT Illiquidity! Journal of Financial Stability, 37, pp. 107-111. https://doi.org/10.1016/j.jfs.2018.03.009

120. Thompson, G. [et al.], 1991. Markets, Hierarchies and Networks: The CoOrdination of Social Life, eds. London: SAGE.

121. Thorelli, H.vB., 1986. Networks: Between markets and hierarchies. Strategic Management Journal, 7, pp. 37-51.

122. Treadway, D. C. [et al.], 2005. Political Will, Political Skill and Political Behavior. Journal of Organizational Behavior, 26, pp. 229-245. https://doi. org/10.1002/job.310

123. Tsyvinski, A, and Werquin, N., 2018. Generalized Compensation Principle. NBER Working Paper, No. 23509.

124. TWI2050 - The World in 2050 (2018). Transformations to Achieve the Sustainable Development Goals. Report prepared by the World in 2050 initiative. International Institute for Applied Systems Analysis (IIASA), Laxenburg, Austria.

125. UNCEPA, 2019. Report on the $18^{\text {th }}$ Session. Economic and Social Council, Official Records 2019, Supplement No. 4. New York: United Nations. https:// doi.org/10.18356/5772c390-en 
126. UNDESA, 2019. The Future is Now - Science for Achieving Sustainable Development. New York: United Nations, Department of Economic and Social Affairs. https://doi.org/10.18356/22f1902c-en

127. United Nations, 2019. Financing for Sustainable Development Report 2019. New York: United Nations. https://doi.org/10.18356/9444edd5-en

128. Van den Bergh, J. C., 2007. Evolutionary Thinking in Environmental Economics. Journal of Evolutionary Economics, 17, pp. 521-549. https://doi. org/10.1007/s00191-006-0054-0

129. WEF, 2019. Global Risks Report - 2019. Geneva: World Economic Forum.

130. Wei, S.J., 1997. Gradualism versus Big Bang: Speed and Sustainability of Reforms. Canadian Journal of Economics, 30(4), pp. 1234-1247. https://doi. org/10.2307/136319

131. Weitzman, M. L., 1993. Economic transition: can theory help? European Economic Review, 37, pp. 549-555. https://doi.org/10.1016/0014-2921 (93)90044-b 